\title{
PENGGUNAAN MODEL CONTEXTUAL TEACHING AND LEARNING ( CTL ) DALAM MENGHADIRKAN KEMAMPUAN BERFIKIR SEJARAH PESERTA DIDIK
}

\author{
Miftahul Jannah \\ E-mail : 1710111220014@mhs.ulm.ac.id \\ Program Studi Pendidikan Sejarah Universitas Lambung Mangkurat \\ Banjarmasin
}

\begin{abstract}
Abstrak : Pembelajaran sejarah merupakan pembelajaran yang dituntut untuk menghadirkan kesadaran sejarah sebagai tujuan utama dalam setiap pembelajaranya. Dalam pelaksanaannya, tujuan tersebut dapat dicapai melalui berbagai model pembelajaran. Salah satunya model contextual teaching and learning ( CTL ).

CTL adalah suatu model pembelajaran yang menekankan kepada proses keterlibatan peserta didik secara penuh untuk menemukan materi yang dipelajari dan menghubungkannya dengan situasi kehidupan nyata. Belajar dalam kontekS CTL bukan hanya sekedar mendengarkan atau mencatat, tetapi merupakan proses belajar dimana peserta didik merasakan pengalaman secara langsung, sehingga dapat mendorong kemampuan berfikir sejarah peserta didik untuk dapat menerapkan dalam kehidupan mereka.
\end{abstract}

Kata kunci : model CTL dan berfikir sejarah

\section{PENDAHULUAN}

Pemahaman merupakan tingkatan kemampuan berfikir seseorang dalam menemukan, menangkap dan mengartikan suatu konsep dengan kata - kata atau simbol yang dipilihnya sendiri. Pemahaman setiap individu seringkali tergantung pada proses yang mengantarkannya menuju pemahaman tersebut. Sebelum seseorang mampu menggambarkan sesuatu, ia akan dihadapkan pada posisi tidak seimbang yang akan menimbulkan kebingungan. Manakala gambaran tersebut telah disempurnakan, seseorang akan ada diposisi seimbang sebelum ia menemukan pemahaman maupun mengalaman baru.

Misalnya : berkat pengalamannya seorang anak memiliki gambaran tentang burung merpati yang memiliki sayap dan bisa terbang. Hal ini akan mengantarkan 
pada pemahaman bahwa setiap binatang bersayap adalah burung, dan setiap burung dapat terbang. Proses selanjutnya ketika ia melihat burung lain yang bisa terbang seperti burung yang lebih kecil dari merpati yaitu burung pipit dan burung yang lebih besar seperti burung elang, akan menyempuranakan gambaran yang dimiliki seorang anak tadi. Bahwa burung memiliki bentuk dari besar hingga kecil. Kemudian ketika seorang anak melihat ayam, dia berada diposisi tidak seimbang karena ragu. Sebab, walaupun ayam bersayap, seorang anak akan menolak jika ayam yang ia lihat dimasukkan kedalam konsep burung yang telah ada, karena ayam memiliki karakteriktik lain. Melalui pengalaman itulah seorang anak akan memaksa untuk membuat skema baru tentang binatang yang bersayap. Inilah yang dinamakan proses pembentukan gambaran berkat pengalaman. ( Sanjaya 2006 : 258 - 259 )

Terkait dengan pembelajaran sejarah. Sejarah adalah jalan untuk menuju pemahaman yang realistis terhadap keadaan masa sekarang, sebagai hasil mempelajari masa lalu yang akan menjadikan manusia menjadi lebih bijak dalam membuat keputusan-keputusan hidup. Dengan demikian pemahaman sejarah merupakan pemahaman tentang perubahan kehidupan manusia di masa lalu melalui gagasan-gagasannya yang mempunyai akibat terhadap kehidupan kita dimasa sekarang dan akan datang. Dalam konteks ini, sejarah adalah cara dalam menanamkan konsep-konsep; nasionalisme, persatuan, solidaritas dan integritas sosial tersebut. Konsep tersebut dapat kita temukan dalam sejarah perjuangan bangsa Indonesia melawan kolonialisme dan imperialisme bangsa lain. Nasionalisme dalam tataran ini adalah ideologi perjuangan bangsa Indonesia dalam melawan kolonialisme dan imperialisme. ( Susanto, $2014: 8$ - 10)

\section{MODEL CONTEXTUAL TEACHING AND LEARNING ( CTL ) DALAM PEMBELAJARAN SEJARAH}

Model pembelajaran Contextual Teaching and Learning (CTL) adalah suatu pembelajaran yang menekankan kepada proses keterlibatan siswa secara penuh untuk dapat menemukan materi yang dipelajari dan menghubungkannya dengan situasi kehidupan nyata sehingga mendorong siswa untuk dapat menerapkannya dalam kehidupan mereka (Sanjaya, $2006: 255$ ).

Mendorong peserta didik untuk dapat mnemukan hubungan antara materi yang

dipelajari dengan situasi kehidupan nyata, menuntut peserta didik untuk dapat menangkap hubungan antara pengalaman belajar dengan realita kehidupan. Dengan 
kemampuan siswa untuk menghubungkan, memungkinkan materi pembelajaran akan bersifat fungsional dan akan tertanam secara erat dengan memory peserta didik.

Menurut pembelajaran kontektual, pengetahuan itu akan bermakna apabila di temukan dan dibangun sendiri oleh peserta didik. Pengetahuan yang diperoleh dari hasil pemberitahuan orang lain, tidak akan menjadi pengetahuan yang bermakna. Pengetahuan yang demikian akan mudah dilupakan dan bisa saja menjadi tidak fungsional. Dengan hakikat belajar untuk menangkap pengetahuan dari kenyataan. Membawa pengetahuan yang diperoleh merupakan pengetahuan yang memiliki makna untuk kehidupan anak.

Berkaitan dengan masalah ini, Taufik Abdulah (2001) mengatakan bahwa dalam kenyataannya materi pengajaran sejarah seringkali diwarnai mitos-mitos sejarah yang justru akan meracuni pola pikir peserta didik. Meskipun pada bagian lain dikatakan bahwa semua ikatan sosial memerlukan mitos, karena mitos tersebut mengajukan jawaban bagi kemungkinan terdapatnya ketimpangan antara realita dan logika, akan tetapi menempatkan mitos yang tidak pada tempatnya justru akan merusak kesadaran kritis kebangsaan dan hanya menghasilkan integritas emosional yang rapuh.

Tidak salah kiranya apabila pelajaran sejarah dikatakan pelajaran yang abstrak, karena meskipun peristiwa sejarah tersebut benar-benar terjadi di masa lalu akan tetapi bagaimanapun tidak dapat dilihat lagi dan diamati di masa sekarang saat sejarah tersebut diajarkan. Keadaan ini memberi petunjuk bahwa sebenarnya belajar sejarah tidak cukup hanya tahu dan hapal, akan tetapi seharusnya lebih diarahkan pada tingkat pemahaman. Dari pemahaman inilah akan terbentuk sekumpulan belief, dan dari belief inilah peserta didik akan mendapatkan dan memahami nilai. Belief disini bukanlah sekedar percaya akan suatu peristiwa, akan tetapi juga meyakini bahwa dari peristiwa tersebut mereka dapat memperoleh sesuatu yang berguna bagi kehidupannya di masa yang akan datang. (Susanto, $2014: 50$ )

Pada tingkat lanjutan atas, siswa sebenarnya sangat haus dengan pengalaman dan ide baru diluar yang mereka pikirkan, meskipun mereka juga belum bisa lepas dari kungkungan super ego dalam diri mereka. Ini jelas artinya bahwa guru harus menunjukkan nilai-nilai dalam tiap gagasan yang melatar belakangi setiap peristiwa sejarah sehingga peristiwa tersebut mempunyai arti untuk generasi setelahnya. Dengan cara seperti ini siswa akan memahami bagaimana jiwa jaman pada saat peristiwa tersebut berlangsung dan akan membuat sejumlah perbandingan dengan keadaan mereka dimasa sekarang. Sehingga apa yang mereka pelajari akan menjadi 
nasihat yang akan membantu mereka mempersiapkan masa depan. ( Susanto, 2014 : $51)$.

Kelemahan yang seringkali diperkatakan dalam aspek pengajaran dan pembelajaran sejarah ialah guru tidak menyediakan peluang dan aktivitas kepada pelajar untuk membangkitkan emosi dan merangsang pemikiran mereka tentang isu-isu sejarah, malahan guru juga tidak kerap menggunakan bahan bantuan yang sesuai sehingga pengajaran menjadi hambar dan tidak memberikan pengalaman yang menarik kepada pelajar Pembelajaran sejarah menjadi amat bermakna jika guru dan pelajar memahami konteks peristiwa dan pemikiran yang muncul daripada satu-satu peristiwa sejarah agar dapat dikembangkan secara lebih mendalam sebagai asas perbincangan dan analisis berstruktur sehingga iktibar dan pengajaran boleh diambil sebagai satu panduan.

Banyak manfaat dan kelebihan yang boleh diperolehi apabila pelajar menggunakan pemikiran ketika belajar bukan hanya menghafal dan mengingat kembali, kerana pelajar dapat dilatih menemukan permasalahan dan mencari jawapan terhadap satu-satu fenomena sejarah. Melalui cara ini, pembelajaran sejarah akan lebih bersifat saintifik, hidup dan membangkitkan minat. Oleh sebab itu, sudah tiba masanya pendekatan pengajaran sejarah berubah agar tidak lagi dilabel pasif, membosankan dan tidak hidup.( Ersis,dkk. 2017 : 49)

Berdasarkan uraian diatas dapat disimpulkan bahwa penggunaan model Contextual teaching and learning ( CTL ) perlu diterapkan dalam pembelajaran sejarah sesuai dengan permasalahan yang ada. Pembelajaran sejarah akan tertanam apa bila peserta didik mendapat pengalaman langsung dari apa yang ia pelajari untuk digunakan dalam mempersiapkan atau menyikapi masa mendatang.

\section{MODEL CONTEXTUAL TEACHING AND LEARNING ( CTL ) DALAM MENGHADIRKAN KEMAMPUAN BERFIKIR SEJARAH}

Kemahiran berfikir sejarah merujuk kepada proses dan aktiviti yang mendorong pelajar untuk berfikir sebelum, ketika dan selepas proses pengajaran dan pembelajaran. Para pelajar dilatih untuk menilai segala peristiwa dengan pandangan seorang pengkaji menggunakan analisis kronologi, analogi waktu, interpretasi terhadap tindakan tokoh sejarah dan imaginasi tentang masa silam dalam gambaran masa kini bagi membolehkan nilai-nilai pengajaran dan perkaitan dengan masa kini dilakukan. Dengan cara itu, pembelajaran lebih bermakna dan pelajar akan berasa 
yakin dan seronok belajar sejarah. Manakala pemikiran sejarah merujuk kepada aspek kepada memahami kronologi, meneroka bukti, membuat interpretasi, imaginasi, membuat rasionalisasi, dan empati. ( Ersis, dkk. 2017 : 50 )

Menurut Seixas (1996) pelajar perlu diajar menilai kepentingan sejarah melalui pembuktian yang dapat dilihat dalam perjalanan peristiwa serta perkembangan yang berlaku samada berterusan atau memberi impak jangka panjang kepada masyarakat. Disinilah penterjemahan dapat dibuat berdasarkan kesannya kepada masyarakat dan zaman selepasnya. Sebagai contoh, ketika membicarakan konflik perang, perkara-perkara berkaitan bahaya perang boleh dijadikan asas perbincangan dengan mengemukakan bukti-bukti berasaskan perkembangan yang terjadi semasa Perang Dunia Kedua dan kesannya kepada masyarakat yang terus berlanjutan hingga ke hari ini. Walau bagaimanapun kebijaksanaan guru sejarah amat diperlukan dalam merungkai sesuatu fenomena dalam peristiwa sejarah.

Tidak kalah pentingnya dalam sejarah banyak terdapat ajaran moral yang dapat dikembangkan menjadi nilai-nilai karakter. Membaca tentang sejarah pergerakan nasional misalnya, kita dapat melihat bagaimana peran generasi muda dalam perjuangan bangsa. Generasi muda dalam perjuangan ini adalah generasi muda yang memiliki kapabilitas, integritas dan moralitas yang tinggi. Keteguhan untuk memperjuangkan kepentingan bersama dan keteguhan mempertahankan idealisme juga menjadi nilai karakter yang seharusnya dikembangkan kembali pada konteks kekinian sehingga generasi muda memiliki sikap yang memperkuat kebangsaan dan tidak mudah larut dalam euporia setiap tren kehidupan modern. ( Susanto, 2014: 30 )

Tally dan Goldenberg (2005) mengakui proses berfikir dapat mengangkat martabat mata pelajaran Sejarah ke tahap yang berbeza berbanding pengajaran lazim, kerana melalui cetusan idea dan pemikiran, pelbagai aspek kebudayaan boleh dibincangkan dengan lebih meluas sekaligus menjadikan pengajaran dan pembelajaran lebih menarik dan menimbulkan keterujaan kepada pelajar. Jelas sekali kajian yang dilakukan membuktikan bahawa amalan pedagogi dan proses berfikir hendaklah selari kerana tanpa keupayaan guru merangka aktiviti dan langkah-langkah pengajaran yang berkesan, tentu sekali pelajar akan mengalami proses pembelajaran yang terhadap dan menyekat peluang mereka untuk membuat tafsiran dan percambahan idea berkaitan bahan pembelajaran.

Dalam proses pembelajaran kontekstual, guru perlu memahami tipe belajar dalam dunia peserta didik, artinya guru perlu menyesuaikan gaya belajar dalam proses 
pembelajaran konvensional, hal ini seringkali terlupakan dan berakibat terhambatnya pencapaian tujuan dalam pembelajaran. Guru perlu memperhatikan peserta didik sebagai individu yang sedang berkembang. Kemampuan belajar seseorang akan dipengaruhi oleh pengalaman yang dimilikinya. Dengan demikian, peran guru bukanlah sebagai instrukur yang memaksakan kehendak, melainkan guru addalah pembimbing peserta didik agar mereka dapat belajar sesuai dengan tahap berkembangannya. Guru disini memiliki peran penting sebagai penyempurna skema berfikir peserta didik agar sesuai dengan pengalaman belajar mereka, sehingga dengan mudah peserta didik dapat terdorong untuk berfikir sejarah.

\section{DAFTAR PUSTAKA}

Sanjaya, Wina 2006. Strategi Pembelajaran. Bandung : Kencana Prenadamedia Group

Susanto, Heri. 2014. Seputar Pembelajaran Sejarah (Isu, Gagasan dan Strategi

Pembelajaran). Banjarmasin : Aswaja Pressindo

Susanto, H. (2016). Pendidikan dan Kesadaran Nasionalisme.

Abbas, E. W , dkk. 2017. Pendidikan sejarah, Patriotisme, dan Karakter Bangsa Indonesia - Malaisya. Banjarmasin : Program Studi Pendidikan IPS dan Program Studi Pendidikan sejarah FKIP Universitass Lambung Mangkurat

Budiningsih, A. (2008). Pembelajaran Moral. Jakarta: Rineka Cipta.

Lie, Anita. 2005. Cooperative Learning. Jakarta : Grasindo

Sanjaya, Wina. 2004. Pengembangan Kurikulum dan Pembelajaran. Bandung : San Grafika

Sanjaya, Wina. 2005. Pembelajaran Dalam Implementasi Kurikulum Berbasis Kompetensi. Jakarta : Kencana, Prenada Media Group

Seixas, P. 1996. Conceptualizing the Growth of Historical Understanding. Dlm.

Olson, D.R. and Torrance, N. (pnyt.) The Handbook of Education and Human Develop

Tally B. dan Goldenberg. L. B. 2005. Fostering Historical Thinking with Digitized Primary Sources. Journal of Research on Technology in Educ 